\title{
Removal of Cu Metals from Wastewater by Adsorption using Synthetic Zeolites from Rice Husk and Corncob
}

\author{
Imas Solihat ${ }^{1}$, Lilis Sulistiawaty ${ }^{*}$, Putri Hawa Syaifie ${ }^{2}$, Agus Taufiq $^{1}$ \\ 'Bogor AKA Polytechnic, Bogor, 16680, Indonesia \\ ${ }^{2}$ Department of Chemistry, Faculty of Mathematics and Natural Sciences, Universitas Indonesia, \\ Depok, 16424, Indonesia
}

*Corresponding author email: lilis.anira@gmail.com

Received October 09, 2019; Accepted June 06, 2020; Available online July 27, 2020

\begin{abstract}
Heavy metals, such as Cu, are hazardous components so that it needs to reduce their concentration due to their negative impact on the environment. One method that can be used to reduce heavy metals in waste is to use adsorbents (synthetic zeolites). Utilization of agricultural waste such as rice husks and corncobs as precursors of synthetic zeolites will add economic value because it is relatively cheap with a lot of availability. This research aimed to find out new variants of synthetic zeolites, which can reduce the concentration of $\mathrm{Cu}$ in the adsorption process. The study consisted of 3 stages, the first stage was zeolite synthesis by the sol-gel method with 3 zeolite variants (,$B$ and $C$ ), the second stage was characterization using XRD and SEM, and the third stage was zeolites optimization (variations in $\mathrm{pH}$, weight, and concentration). According to the results of SEM, zeolite B had a larger and uniform pore size so as it produced a greater adsorption capacity $(4.82 \mathrm{mg} / \mathrm{g})$ to be compared with zeolites $A$ and $C$. The results showed synthetic zeolite $C$ was able to adsorb Cu waste by following the adsorption isotherm model of Langmuir.
\end{abstract}

Keywords: Corn Cobs, Heavy Metal, Rice Husk, Zeolites Adsorbent

\section{INTRODUCTION}

The issue of environmental pollution has recently become a great concern topic because it will have an impact on human health. One of the pollutions is the presence of heavy metals such as copper (Cu) metal. Heavy metals are pollutants that cannot be biodegradable because they are very difficult to remove naturally (Abas, Ismail, Kamal, \& Izhar, 2013). Copper Metal (Cu) will cause damage to the liver and kidneys, even in high doses, can cause death.

Treatment that can be done to reduce the content of heavy metals is by deposition, membrane filters, ion exchange, and adsorption (Hegazi, 2013). One alternative method that can be developed is the adsorption method using synthetic zeolites. The use of synthetic zeolites is more than natural zeolites because synthetic zeolites have a higher level of purity and pore uniformity than natural zeolites. Based on research by Ghifari et al. (2017), zeolite synthesis produces greater adsorption efficiency compared to natural zeolites in the adsorption of dyes. The manufacture of synthetic zeolites requires a source of silicate and aluminate. Silicate is obtained from rice husks and corn cobs that have been made up while aluminate is obtained from sodium aluminate. Silica source plays an important role in the synthesis process and also determines the morphology of the synthesized product (Zhang, Li, Liu, \& Wang, 2019).

Agricultural wastes that can be used as sources of silica include rice husks (Islam, Liu, Shen, Ye, \& Peng, 2018; Arneli, Solichah, Alfiansyah, Suseno, \& Astuti, 2017), wheat husk ash (Shaikh et al., 2015) and teak sawdust (Saputro et al., 2017). Silica ash is widely used for various chemical processes, including dessicants, adsorbents, filter media, and catalyst components. According to Arneli, Pangestika, Fauziah, Wahyuningrum, \& Astuti (2017), the silica content in rice husks is around $86.9-97.8 \%$ and in corncobs is $79,95 \%$ (Wardhani, Nurlela, \& Azizah, 2017). Besides its high silica content, rice husks and corncobs can be obtained at a low cost. Their availability is abundant, and then they can be renewed so that they can be used as the new variant of synthetic zeolites. Existing research uses only one source of raw materials. The novelty of this research is to use 2 types of raw materials (a combination of rice husks and corncobs).

The zeolites synthesis method commonly used is the sol-gel method, hydrothermal method and microwave method. In this study, silica was isolated from rice husk ash and corncob ash using the sol-gel method due to the fact that it is simpler than the hydrothermal method, then the characterization was conducted with 
XRD and SEM parameters, optimization was done by taking notice of the variations in $\mathrm{pH}$, weight, and concentration. This research was important to do because it could find out new variants of synthetic zeolites that could reduce the concentration of metals in $\mathrm{Cu}$ waste in the adsorption process and add value to the use of rice husks and corncobs.

\section{EXPERIMENTAL SECTION}

The research method consisted of 3 stages: the manufacturing of synthetic zeolites by the sol-gel method in 3 variations in composition between rice husk ash, corncob ash, and aluminate; then characterizing with XRD and SEM and zeolite optimizing with the variations in $\mathrm{pH}$, weight, and concentration.

\section{Materials}

The material in this study used rice husks, corncobs, aluminum hydroxide, sodium hydroxide, distilled water, distilled water, universal $\mathrm{pH}$ paper, filter paper, $\mathrm{Cu}\left(\mathrm{NO}_{3}\right)_{2}$ solution.

\section{Instrumentation}

AAS (Shimadzu 2010), X-ray Diffraction, Scanning Electron Microscope, Cu cathode lamp, analytical balance (Shimadzu), shaker (Heidolf), furnace (Memert), pH meter (Agilent) and other glassware.

\section{Synthesis and characterization of zeolites}

Rice husks and corncobs were obtained from the Karawang area, West Java. Before synthesized, the raw material was made with a furnace and ground using a mortar to increase the surface area. $10 \mathrm{~g}$ of rice husk ash was dissolved in $6 \mathrm{~N} \mathrm{NaOH}$ solution for 24 hours (solution a), then corn cobs ash was treated in the same manner as in rice husk ash (solution b). Aluminate was made by weighing $25 \mathrm{~g}$ of aluminum hydroxide dissolved in $30.5 \mathrm{~g}$ of sodium hydroxide (solution c). Solutions $a, b$, and c were then put into $a$ Duran bottle up to a volume of $100 \mathrm{~mL}$ with the composition of the formulation ( $A, B$, and $C$ ), then all variations of the composition were heated in an oven at $105{ }^{\circ} \mathrm{C}$ for 24 hours. Furthermore, all of the treatments were filtered and washed with distilled water to a neutral $\mathrm{pH}$ using a universal $\mathrm{pH}$, then roasted at $105{ }^{\circ} \mathrm{C}$ for 8 hours. The composition of synthetic zeolites can be seen in Table 1. Zeolite products were analyzed by XRD to determine crystallinity and SEM to determine solid morphology.

Table 1. Zeolite synthesis composition

\begin{tabular}{cc}
\hline $\begin{array}{c}\text { The name zeolite } \\
\text { synthesis }\end{array}$ & $\begin{array}{c}\text { Composition } \\
\text { (corn cobs: rice husk: sodium aluminate) }\end{array}$ \\
\hline A & $60: 20: 20$ \\
B & $50: 25: 25$ \\
C & $40: 30: 30$ \\
\hline
\end{tabular}

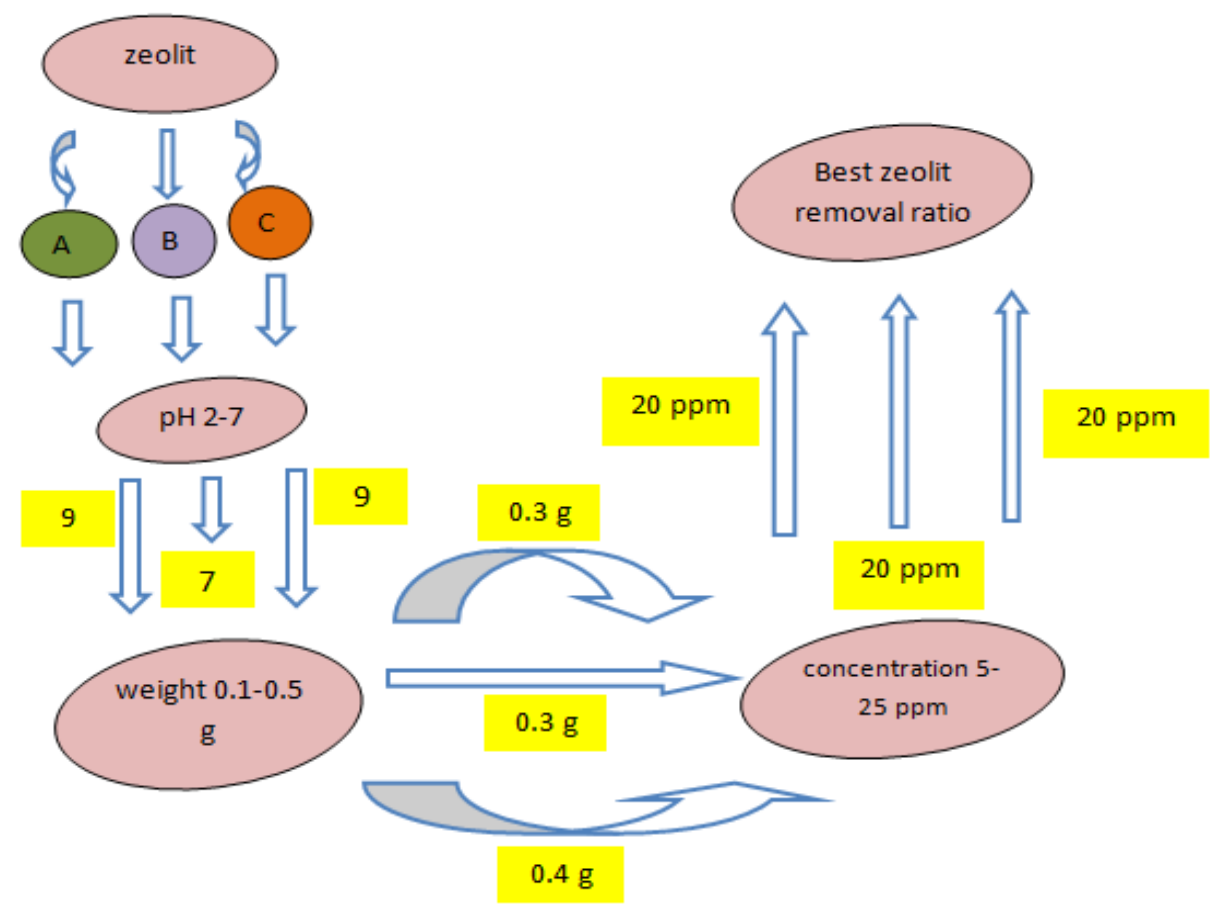

Figure 1. Experimental work optimization of synthetic zeolites adsorption with Cu metal 


\section{Optimization of synthetic zeolites adsorption with $\mathrm{Cu}$ metal}

Optimization was done to find out the optimum weight of zeolites to adsorb $\mathrm{Cu}$ metal at certain concentrations and $\mathrm{pH}$. In this step, the first step was to optimize the $\mathrm{pH}$ of $\mathrm{Cu}$ solution in which zeolite was weighed 0.1 gram then added $25 \mathrm{~mL}$ of $\mathrm{Cu}$ solution $10 \mathrm{ppm}$ with a variation of $\mathrm{pH} \mathrm{2,4} 7$ and 9 using a $\mathrm{pH}$ meter then shaker for 30 minutes, and the filtrate was taken to measure the concentration of the remaining $\mathrm{Cu}$ by using AAS. The second stage was the optimization of zeolite weights with a variation of 0.1-0.5 grams and the third stage was the optimization of the concentration of $\mathrm{Cu}$ with a variation of $5,10,15$ and $25 \mathrm{ppm}$. The optimization work step can be seen in Figure 1. Cu concentration after adsorption (residual) could be determined by calculating $\mathrm{Cu}$ concentration using the equation $y=a+b x$ with the condition: adsorbed concentration $=$ initial concentration - residual concentration.

Determination of adsorption capacity was carried out under the optimum $\mathrm{pH}$ of $\mathrm{Cu}$ solution and zeolite weights, but the variation of concentration was carried out with fixed stirring speed $(200 \mathrm{rpm})$ for 30 minutes and room temperature (Al-Senani \& Al-Fawzan, 2018). The adsorption capacity was calculated from the Langmuir equation (1) or the Freundlich equation (2).

$$
\begin{aligned}
& \frac{C e}{q e}=\frac{1}{Q 0 b}+\frac{C e}{Q 0} \\
& \log \left(\frac{x}{m}\right)=\log k+\frac{1}{n}(\log c)
\end{aligned}
$$

The determination of the adsorption isotherm model was done by changing the Langmuir or Freundlich isotherm equation into a straight line equilibrium curve. The determination of the equilibrium model depended on the determinant coefficient $(R)$ with a high value.

\section{RESULTS AND DISCUSSION \\ Synthesis of zeolites}

Raw materials for making synthetic zeolites had to have a high silica content, one of which was contained in rice husks and corncobs. Information about rice husks and corncobs can be seen in Table 2. In this study, silica from rice husks and corncobs was isolated by the thermal method. After cleaning, rice husk and corn cobs were then made using stove furnaces and followed by ashes at $600{ }^{\circ} \mathrm{C}$ for 2 hours to produce corn cobs ash and rice husks as silica sources. The resulting powder was still slightly blackish color caused by other residues such as carbon and several other types of oxides that were still left behind. Besides the thermal method of silica isolation, silica can also be isolated by non-thermal methods, namely by using $\mathrm{HCl}$ solution. Research conducted by Wardhani, Nurlela, \& Azizah (2017) produces silica from brown rice husk ash using non-thermal methods. Silica from rice husk ash and corncobs was dissolved with $\mathrm{NaOH}$ to produce sodium silicate. The reaction to the formation of sodium silicate is shown in Figure 2.

According to Kong et al. (2019) research, zeolite can be synthesized from sodium aluminate (a mixture of $\mathrm{NaOH}$ and $\mathrm{Al}(\mathrm{OH})_{3}$ in hot distilled water) and silica using temperature conditions of $100{ }^{\circ} \mathrm{C}$. This heating aims to perfect the crystal growth between aluminate salts and silicate salts. The results of the mixture form a white gel that shows the interaction between the two because the polymerization process has occurred (Ojha et al., 2004). Furthermore, crystals are formed due to the heating process in the gel form.

$$
\begin{aligned}
& {\left[\mathrm{Na}_{x}\left(\mathrm{AlO}_{2}\right)_{y}\left(\mathrm{SiO}_{2}\right)_{z} \cdot \mathrm{NaOH} \cdot \mathrm{H}_{2} \mathrm{O}\right](\text { gel }) \rightarrow} \\
& \left.\mathrm{Na}_{\mathrm{p}}\left[\left(\mathrm{AlO}_{2}\right)_{\mathrm{p}}\left(\mathrm{SiO}_{2}\right)_{\mathrm{q}}\right]_{\mathrm{h}} \mathrm{H} 2 \mathrm{O}\right] \text { (crystal) }
\end{aligned}
$$

The resulting crystalline solids are then washed with distilled water to a neutral $\mathrm{pH}$ to remove excess reagent from the adsorbent (Adeniyi et al., 2019). The next step is drying to evaporate the water trapped in the zeolite pores. Dehydrated zeolite will have an open pore structure with a large surface area so that it has

\begin{tabular}{|c|c|c|c|c|c|}
\hline Adsorbent & Main consistent & $\begin{array}{c}\text { Primary } \\
\text { source }\end{array}$ & \multicolumn{2}{|c|}{$\begin{array}{c}\text { Chemical } \\
\text { characterization (\%) }\end{array}$} & Primary uses \\
\hline $\begin{array}{l}\text { Rice husk } \\
\text { (Chun, Gu, } \\
\text { Hwang, Oh, \& } \\
\text { Lee, 2019) }\end{array}$ & $\begin{array}{l}\text { The outer side } \\
\text { of rice, obtained } \\
\text { from rice grains } \\
\text { stripping }\end{array}$ & Rice & $\begin{array}{c}\mathrm{SiO}_{2} \\
\mathrm{~K}_{2} \mathrm{O} \\
\mathrm{MgO} \\
\mathrm{Al}_{2} \mathrm{O}_{3} \\
\mathrm{CaO} \\
\mathrm{Fe}_{2} \mathrm{O}_{3}\end{array}$ & $\begin{array}{c}96.34 \\
2.3 \\
0.45 \\
0.41 \\
0.41 \\
0.2\end{array}$ & Wastewater treatment \\
\hline Corncob & $\begin{array}{l}\text { Cotyledon } \\
\text { forming sites } \\
\text { and food } \\
\text { storage }\end{array}$ & Corn & $\begin{array}{l}\text { Contai } \\
\text { fiber si } \\
\text { hemice } \\
\text { and sil }\end{array}$ & $\begin{array}{l}\text { of rough } \\
\text { cellulose, } \\
\text {, lignin }\end{array}$ & Animal feed \\
\hline
\end{tabular}
a large adsorption ability. The chemical structure of zeolite can be seen in Figure 3 .

Table 2. Information about adsorbent resources 


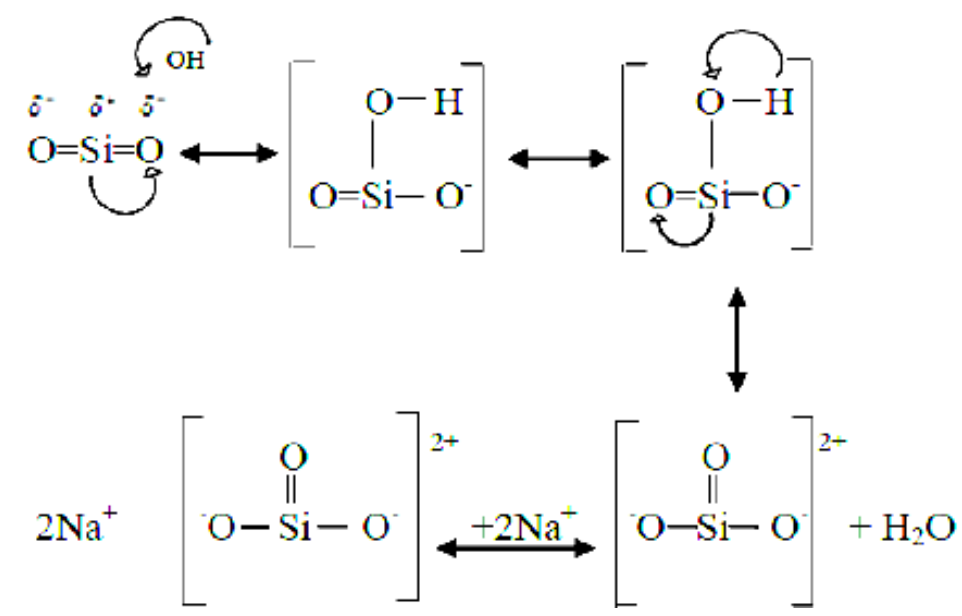

Figure 2. Reaction mechanism of sodium silicate formation (Mujiyanti, Nuryono, \& Kunarti, 2010)

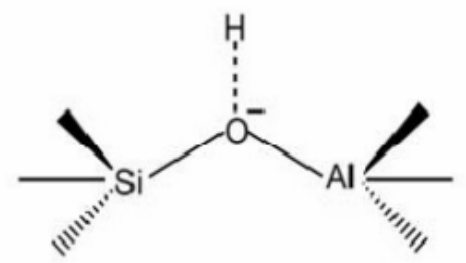

Figure 3. Chemical structure of zeolite (Mgbemere, Ekpe, \& Lawal, 2017)

\section{Characterization of zeolites}

The third characterization of zeolites used XRD and SEM instruments. XRD was used to determine the type of crystals contained in zeolites, while SEM was used to determine the structure of zeolites. The results of XRD and SEM analysis can be seen in Figures 4 and 5 . Characterization with XRD was carried out to determine the structure and types of minerals arranged in synthetic zeolites. From the XRD measurement, the peak for the three zeolites was at $24.3^{\circ} 13,9^{\circ}$, and $34,6^{\circ}$ with the name zeolite sodium aluminum silica hydrate (S) (JCPDS no 42-0216). The crystallinity intensity of zeolite B (2318 CPS) was lower compared to zeolite A (2502 CPS) and C (3094 CPS) at $24.3^{\circ}$.

From the SEM results, it could be seen that the surface of the three zeolites was irregular and porous. Zeolite A had a smaller pore size (122.8-357.3 nm) compared to zeolite B $(332.0-991.9 \mathrm{~nm})$ and $C$ (562.3-823.5 nm).

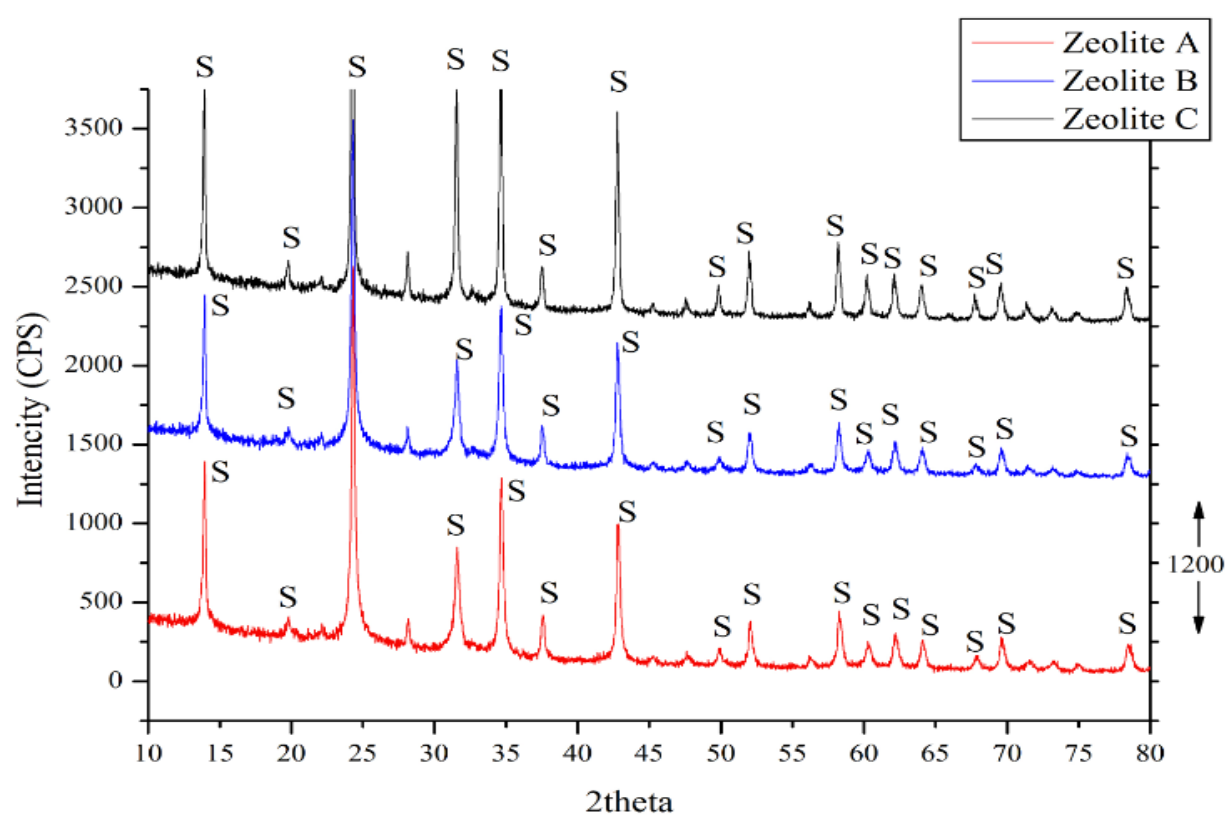

Figure 4. The XRD pattern of zeolite A, zeolite B, and Zeolite C 

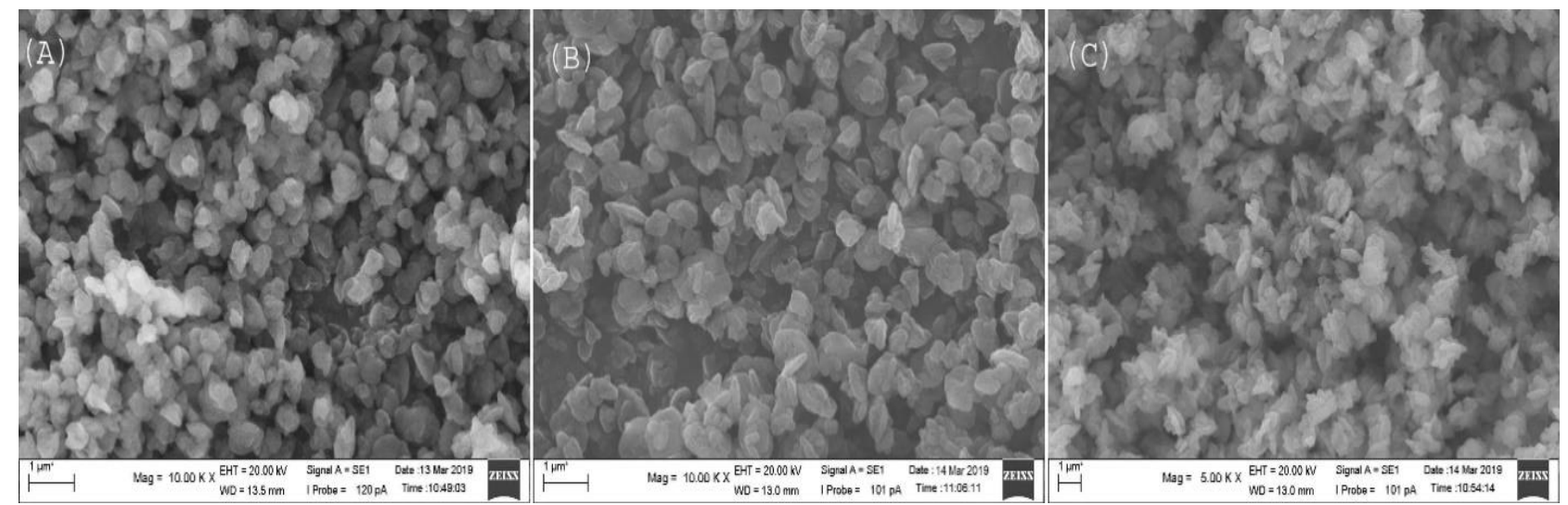

Figure 5. The SEM images of zeolite A (A), Zeolite B (B) and Zeolite C (C)

\section{Optimization of zeolites}

Adsorption is a mass transfer process that involves the accumulation of substances between two phases, such as the liquid-liquid, gas-liquid, gas-solid, or liquid-liquid phase (Gisi et al., 2016). In this study, a batch system was used. Adsorption batch experiment used several bottles containing different weights of the adsorbent. Furthermore, they were added with a $\mathrm{Cu}$ solution with a certain concentration at a certain $\mathrm{pH}$ and shaken for 30 minutes at a speed of 200 rpm.

The effect of adding zeolite weight (0.1-0.5 grams) to the reduction of $\mathrm{Cu}$ ions can be seen in Figure 6 . Based on Figure 6, it was known that the adsorption efficiency increased from 20 to $80 \%$ at a $\mathrm{Cu}$ concentration of $10 \mathrm{ppm}$. The optimum condition for zeolites B and C was 0.3 grams, while for zeolites $\mathrm{A}$ was 0.4 grams. The greater the weight, the lower the \% efficiency. This is caused by the fact that the higher weight has passed the supercritical point so that the dissolved concentration of zeolite decreases (Khuluk, Rahmat, Buhani, \& Suharso, 2019). Based on Salleh, Mahmoud, Karim, \& Idris
(2011), It can be done at one concentration point to see the effect of adding zeolite weight.

Optimization results for the $\mathrm{pH}$ variation from 2 to 9 can be seen in Figure 7. It is important to vary the $\mathrm{pH}$ to determine the efficiency of zeolite adsorption on $\mathrm{Cu}$ metal. At low $\mathrm{pH}$, the positively charged zeolite surface tends not to adsorb cations. In addition, when the $\mathrm{pH}$ increases, the surface of the zeolite is negatively charged so that an electrostatic attraction occurs between the positive charge on the $\mathrm{Cu}$ metal and the negatively charged zeolite (Abd El-Latif \& Ibrahim, 2009).

The effect of variations in concentration on zeolites can be seen in Figure 8. Efficiency increases with the increase of solution concentration. In addition, the optimum adsorption capacity is determined under optimum $\mathrm{pH}$ and zeolite weight. The adsorption capacity tends to increase with the increasing of adsorbate concentration due to increased competition among adsorbates with the active side, which will shift towards the metal complex of the active side (Gupta \& Bhattacharayya, 2008). The curve relationship between adsorption capacity and concentration variations can be seen in Figure 9.

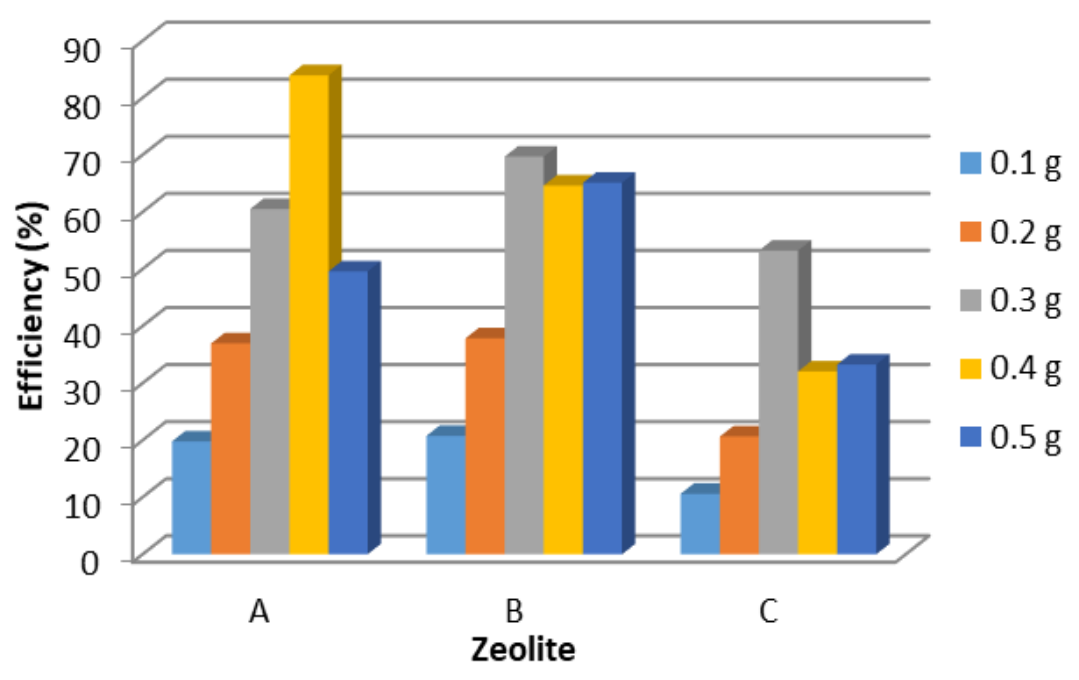

Figure 6. The removal efficiency of various zeolites with different weight 


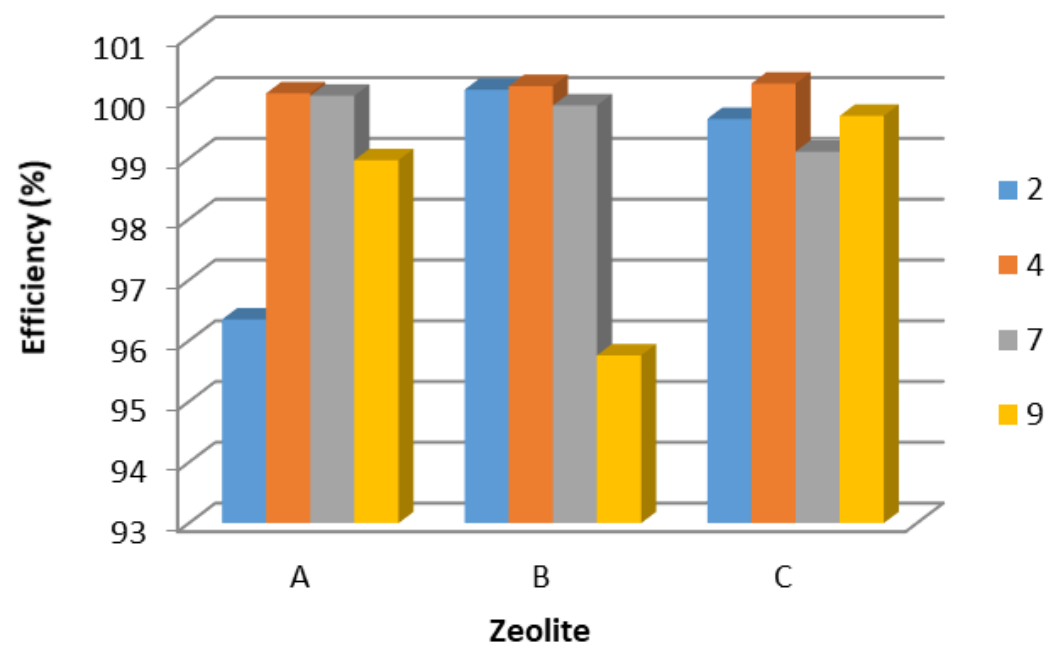

Figure 7. The removal efficiency of various zeolites with different $\mathrm{pH}$

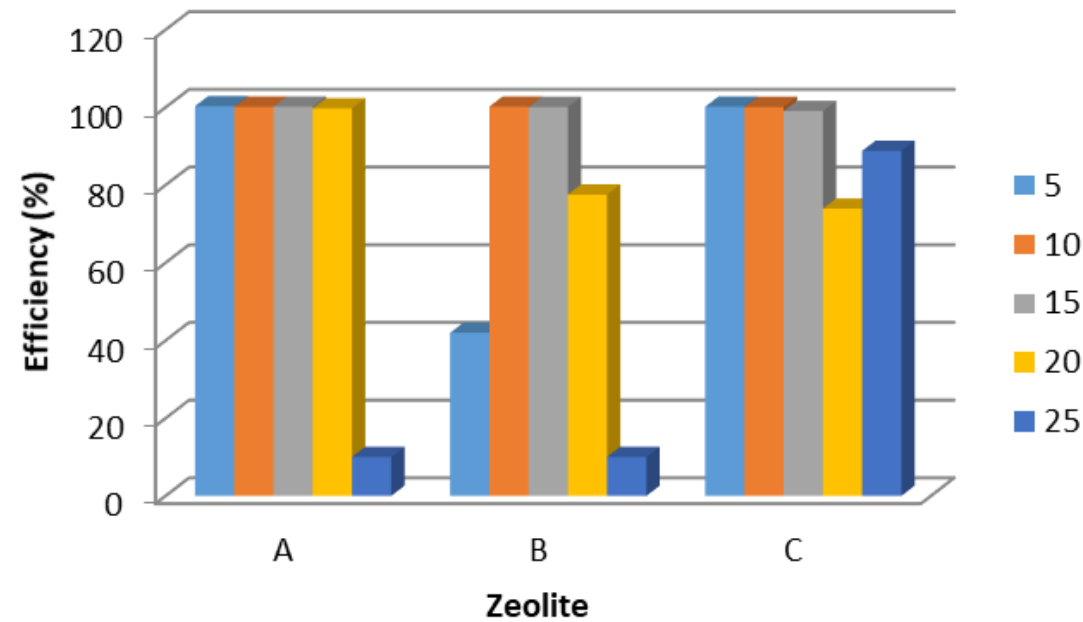

Figure 8. The removal efficiency of various zeolites with different concentration (ppm)

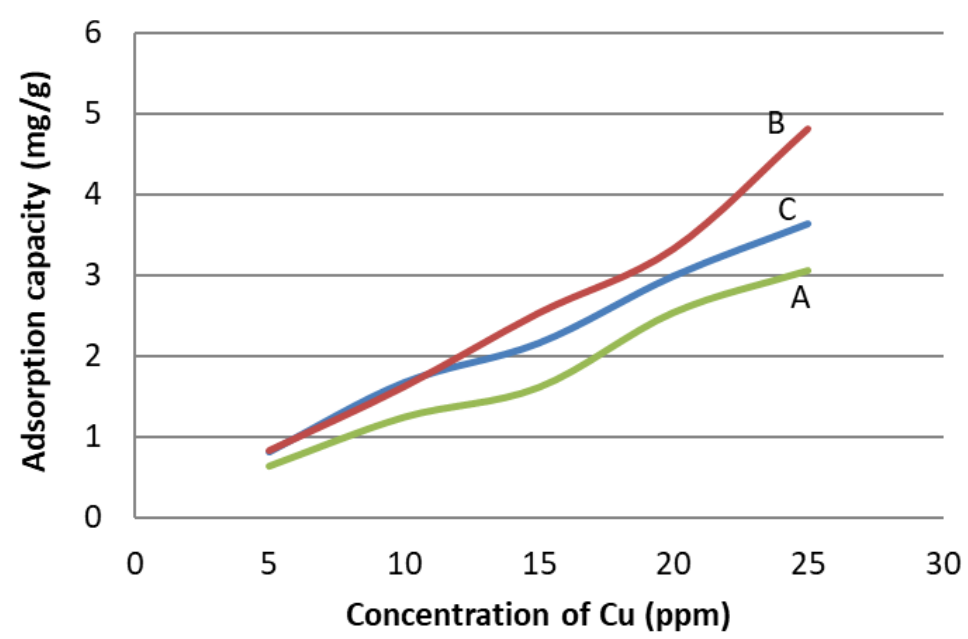

Figure 9. Graph of the relationship between adsorption capacity and concentration variations 

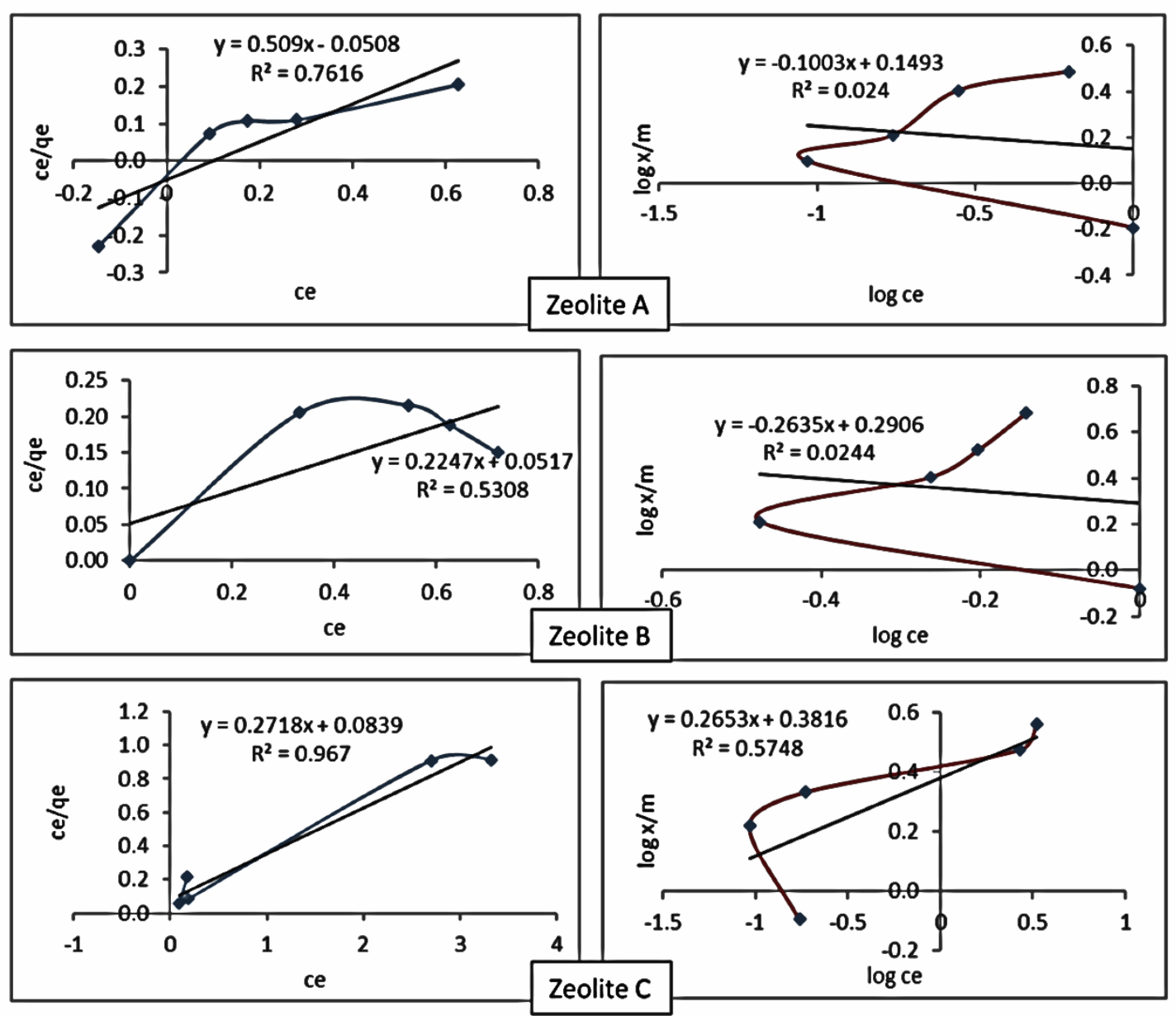

Figure 10. The adsorption isoterm of zeolite [Langmuir (left) and Freundlich (right)]

The adsorption capacity of zeolite $\mathrm{A}$ and $\mathrm{C}$ was $3.63 \mathrm{mg} / \mathrm{g}$ at a concentration of $25 \mathrm{ppm}$, while the adsorption capacity of zeolite $B$ was greater that was $4.80 \mathrm{mg} / \mathrm{g}$. This is caused by the fact that the adsorption ability of zeolite $B$ was higher than zeolite $A$ and $C$ as evidenced by the results of SEM characteristics in which zeolite $B$ had a greater surface area capability so that the adsorption power is better (Charles \& Odoemelam, 2010).

Determination of isotherm adsorption is carried out to determine the molecular distribution between the liquid and solid phase when the adsorption process reaches a balance point (Farghali, Bahgat, \& Khedr, 2013). Common isotherm adsorption models are Langmuir and Freundlich. The application of the isotherm equation is used by comparing the correlation value $\left(R^{2}\right)$. The Langmuir and Freundlich adsorption isotherm model can be seen in Figure 10.

Based on Figure 10, zeolite $C$ follows the Langmuir adsorption isotherm in which the Cu metal adsorption process occurs monolayer on a homogeneous surface, and after that, adsorption does not occur again (Alanber, 2011). Zeolite A and B cannot determine the type of isotherm because the $R^{2}$ values in both were very low. However, further analysis needs to be done with different methods to determine the specific adsorption mechanism for zeolites A and B.

\section{CONCLUSIONS}

The composition of rice husks and corncobs can be used as a new variant of synthetic zeolites containing sodium aluminum silica hydrate. The optimum conditions of zeolite $\mathrm{A}, \mathrm{B}$, and $\mathrm{C}$ adsorption were obtained at $\mathrm{pH} 7-9$, with the zeolite weights of 0.3 and 0.4 grams at $\mathrm{Cu}$ concentration of $20 \mathrm{ppm}$. SEM characterization results showed that zeolite $B$ had a particle shape with larger and more uniform surface area compared to zeolite $A$ and $C$, in which zeolite $C$ follows the Langmuir adsorption isotherm.

\section{ACKNOWLEDGMENTS}

AKA Bogor Polytechnic as a place of research experiments and funding support.

\section{REFERENCES}

Abas, S. N. E., Ismail, M. H. S., Kamal, Md. L., Izhar, S. (2013). Adsorption Process of Heavy Metals by Low-Cost Adsorbent: a review. World Applied Sciences Journal, 28(11), 1518-1530. http://dx.doi.org/10.5829/idosi.wasj.2013.28 .11 .1874 . 
Abd El-Latif, M. M., Ibriahim, A. M. (2009). Adsorption, Kinetic and Equilibrium Studies on Removal of Basic Dye from Aqueous using Hydrolyzed Oak Sawdust. Desalination water treatment, 6(1-3),

252-268. http://dx.doi.org/10.5004/dwt.2009.501.

Adeniyi., Goerge, A., Joshua, I. (2019). Biosorption of Pollutants by Plant Leaves [an empirical review]. Journal of environmental chemical engineering, 7(3).

https://doi.org/10.1016/i.jece.2019.103100.

Al-Anber, M. A. (2011). Thermodynamics Approach in the Adsorption of Heavy Metal. Editor: Juan Carlos Moreno Pirajain. Retrieved from http://www.intechopen.com/book/thermodyna mics-Interaction-StudiesSolid-Liquid-and-

Gases/thermodynamics-approach-in-theadsorptionof-heavy-metal.

Al-Senani, G. M., Al-Fawzan, F.F. (2018). Adsorption Study of Heavy Metal lons from Aqueous Solution by Nanoparticle of Wild Herbs. Egyptian Journal of aquatic research, (44), 187 194.

https://doi.org/10.1016/i.ejar.2018.07.006.

Arnellia., Solichah, F., Alfiansyah., Suseno, A., Astuti, Y. (2017). Sintesis Zeolit dari Abu Sekam Padi menggunakan Metode Hidrotermal : Variasi Waktu dan Temperatur. Journal of Scientific and alpplied chemistry, 20(2), 58-61.

Arnellib., Pangestika, A. W., Fauziah, F., Wahyuningrum, V. N., Astuti, Y. (2017). The Influence of Activating Agents on the Performance of Rice Husk-Based Carbon for Sodium Lauryl Sulfate and Chrome $(\mathrm{Cr})$ Metal Adsorptions. Material Science and Engineering, 172

012007.

http://dx.doi.org/10.1088/1757899X/172/1/012007.

Charles, O., Odoemelam, S. A. (2010). Studies on Adsorbent Dosage, Particle Sizes and $\mathrm{pH}$ Constraints on Biosorption of $\mathrm{Pb}$ (II) and $\mathrm{Cd}$ (II) lons from Aqueous Solution using Modified and Unmodified Srasstrotrea Gasar (bivalve) Biomass. International archive of applied sciences and technology, 1(1), 62-68.

Chun, J., Gu, Y. M., Hwang, J., Oh, K. K., Lee, J. H. (2019). Synthesis of Ordered Mesoporous Silica with Various Pore Structures Using High-Purity Silica Extracted from Rice Husk. Journal of industrial and engineering chemistry, 1-9. http://dx.doi.org/10.1016/i.jiec.2019.08.064.

Farghali, A. A., Bahgat, M., Allah, A. E., Khedr, M. H. (2013). Adsorption of $\mathrm{Pb}$ (II) lons from Aqueous Solutions using Copper Oxide Nanostructures. Beni-suef university journal of basic and applied sciences, 2, 61-71. http://dx.doi.org/10.1016/i.bjbas.2013.01.00 1 .
Gisi, S., Lofrano, G., Grassi, M., Notacnicola, M. (2016). Characteristics and Adsorption Capacities of Low-Cost Sorbents for Wastewater Treatment: a review. Sustainable materials and technologies. 9, 10-40. https://doi.org/10.1016/j.susmat.2016.06.00 2.

Ghifari, A., Nuraini, A., Permatasari, D., Kamila, N., Imanullah, T., Astuti, Y. (2017). Nano-Zeolite Modification using Cetylpiridinium Bromide for the Removal of Remazol Black B and Remazol Yellow G Dyes. Journal of Computational and Theoretical Nanoscience, 23(7), 6502-6505. https://doi.org/ 10.1166/asl.2017.9667

Gupta, S. S., Bhattacharayya, G. K. (2008). Immobilization of $\mathrm{Pb}$ (II), $\mathrm{Cd}$ (II), $\mathrm{Ni}$ (II) lons on Kaolinite and Montmorillonite Surfacefrom Aqueos Medium. Journal of Environment Management, 87, 46-58. https://doi.org/ 10.1016/i.jenvman.2007.01. 048.

Hegazi, H. A. (2013). Removal of Heavy Metals from Wastewater using Agricultural and Industrial Waste as Adsorbents. Housing and Building National Research Center, 9, 276-282. https://doi.org/10.1016/j.hbrci.2013.08.004.

Islam, T., Liv, J., Shen, G., Ye, T., Peng, C. (2018). Synthesis of Chemically Modified Carbon Embedded Silica and Zeolite from Rice Husk to Adsorb Crystal Violet Dye from Aqueous Solution. Applied Ecology and Environmental Research, 16(4), 3955-3967. http://dx.doi.org/10.15666/aeer/1604_3955 3967.

Khuluk, R. H., Rahmat, A., Buhani., Suharso. (2019). Removal of Methylen Blue by Adsorption onto Activated Carbon from Coconut Shell (Cocous Nucifera L.). Indonesian Journal of Science \& Technology, 4(2), 229-240. http://dx.doi.org/10.17509/ijost.v4i2.18179.

Kong, J., Zhu, F., Huang, W., He, H., Hu, J., Sun, C., Xian, Q., Yang, S. (2019). Sol-Gel Based MetalOrganic Framework Zeolite Imidazole Framework-fibers for Solid-Phase Microextraction of Nitro Polycylic Aromatic Hydrocarbon and Polycyclic Aromatic Hydrocarbons in Water Samples. Journal of chromatography A, 1603, 92-101. http://dx.doi.org/10.1016/j.chroma.2019.06. 063.

Mgbemere, H. E., Ekpe, I.C., Lawal, G. I. (2017). Zeolite Synthesis, Characterization and Application Areas: a review. International Research Journal of Environmental Sciences, 6(10), 45-59.

Mujiyanti, D. R., Nuryono., Kunarti, E. S. (2010). Sintesis dan Karakterisasi Silika Gel dari Abu Sekam Padi yang Dimobilisasi dengan 3- 
(Trimetoksilil)-1-Propantiol. Sains dan Terapan Kimia, 4(2), 150-167.

Ojha, K., Narayan, C. P., Amar, N. T. (2004). Zeolite from Fly Ash and Characterization. Journal Sci, 27(6), 555-564.

Salleh, M. A. M., Mahmoud, D. K., Karim, W. A., Idris, A. (2011). Cationic and Anionic Dye Adsorption by Agricultural Solid Wastes: a review. Desalination, 280(1-3), 1- 13. http://dx.doi.org/ 10.9790/5736-5391 108.

Shaikh, I. R., Shaikh, R. A., Shaikh, A. B., War, J. A., Hangirgekar, S. P., Shaikh, A. L., Shaikh, P. R., Shaikh, R. R. (2015). H-ZSM-5 Zeolite Synthesis by Sourcing Silica from the Wheat Husk Ash : Characterization and Application as a Versatile Heterogeneous Catalyst in Organic Transformations Including Some Multicomponent Reactions. Journal of Catalyst. ID 805714 http://dx.doi.org/10.1155/2015/805714.

Saputro, S., Masykuri, M., Mahardiani, L., Mulyani, B., Qorina, I., Yoshimura, K., Takehara, K., Matsuoka, S. (2017). The Usage of Activate
Carbon from Teak Sawdust (tectona grandis I.f) and Zeolite for the adsorption of $\mathrm{Cr}(\mathrm{VI})$ and its Analysis using Solid-Phase Spectrophotometry (sps). Materials Science and Engineering, 176, $012019 . \quad \mathrm{http}: / / \mathrm{dx}$.doi.org/10.1088/1757899X/176/1/012019.

Wardhani, G. A. (2017). Silika pada Tongkol Jagung yang Dikarakterisasi Menggunakan Spektroskopi Infra Merah dan Difrakasi SinarX. Jurnal kimia riset, Vol 2 (1).

Wardhani, G., Nurlela., Azizah M. (2017). Silica Content and Structure from Corncob Ash with Various Acid Treatment $(\mathrm{HCl}, \mathrm{HBr}$, and Citric Acid). Molekul, 12(2), 174-181. http://dx.doi.org/10.20884/1.jm.2017.12.2.3 82.

Zhang, J., Li, X., Liu, J., Wang, C. (2019). A Comparative Study of MPI Zeolite Derivated from Different Silica Source : Synthesis, Characterization and Catalytic Performance. Catalysts, 9(13). http://dx.doi.org/doi:10.3390/catal9010013. 